\title{
GCU
}

Glasgow Caledonian

University

University for the Common Good

\section{Green for Brown (G4B): a novel tool for evaluating phytoextraction in soils polluted by heavy metals \\ Gonzalez-Ollauri, Alejandro; Mickovski, Slobodan B.}

Published in:

Recent Advances in Environmental Science from the Euro-Mediterranean and Surrounding Regions

DOI:

10.1007/978-3-319-70548-4_81

Publication date:

2018

Document Version

Author accepted manuscript

Link to publication in ResearchOnline

Citation for published version (Harvard):

Gonzalez-Ollauri, A \& Mickovski, SB 2018, Green for Brown (G4B): a novel tool for evaluating phytoextraction in soils polluted by heavy metals. in Recent Advances in Environmental Science from the Euro-Mediterranean and Surrounding Regions. Advances in Science, Technology \& Innovation, Springer, pp. 257-258, EuroMediterannean Conference for Environmental Integration, Sousse, Tunisia, 22/12/17. https://doi.org/10.1007/978-3-319-70548-4_81

\section{General rights}

Copyright and moral rights for the publications made accessible in the public portal are retained by the authors and/or other copyright owners and it is a condition of accessing publications that users recognise and abide by the legal requirements associated with these rights.

Take down policy

If you believe that this document breaches copyright please view our takedown policy at https://edshare.gcu.ac.uk/id/eprint/5179 for details

of how to contact us. 


\title{
Green for Brown (G4B): A novel tool for evaluating phytoextraction in soils polluted by heavy metals
}

\author{
Alejandro Gonzalez-Ollauri ${ }^{1,2}$, Slobodan B. Mickovski ${ }^{1}$ \\ ${ }^{1}$ BEAM Research Centre, Glasgow Caledonian University, Cowcaddens Road G4 OBA Glasgow UK \\ ${ }^{2}$ Corresponding author: alejandro.ollauri@gcu.ac.uk
}

\begin{abstract}
Highlights: Green for Brown (G4B) is a novel, open-source, computer-based, and spatially-distributed tool for evaluating phytoextraction in soils polluted by heavy metals. $G 4 B$ operates with easily quantifiable inputs related to the soil, plant, and climate compartments. We evaluate G4B's potential by simulating the arsenic (As) phytoextraction performance of a fern. $G 4 B$ predictions indicate that the tested fern was able to extract $17.23 \mathrm{mg} \mathrm{L}^{-1}$ of As per growing cycle, requiring 8 cycles to restore the soil As to safety level. G4B was shown to be an effective and viable tool for assessing heavy metal phytoextraction from polluted soil.
\end{abstract}

Keywords: Phytoextraction, model, plant, soil, heavy metal, arsenic

\section{Introduction}

Soil pollution is a serious threat to human and environmental health. Previous industrial activity in Scotland has left behind a large brownfield area polluted by heavy metals wich is expensive to treat (GCVSDPA, 2016). Phytoremediation could be an effective and sustainable measure for cleaning contaminated soil (Ansari et al., 2015). Although phytoremediation has been extensively studied over the last two decades, the governing environmental factors are not yet clearly understood. Additionally, there is a severe lack of applied research (Mahar et al., 2016) and holistic models (Ansari et al., 2015) that could contribute to assess clean-up strategies on polluted soil, and to shed light on the environmental factors governing phytoremediation.

The aim of this paper is to introduce and evaluate a simple, holistic, and realistic numerical tool able to predict the phytoextraction of heavy metals from the soil over time.

\section{Material and Methods}

Green for Brown (G4B) is an open-source, computer-based, and spatially distributed tool for the evaluation of the phytoextraction potential of heavy metals from the soil. G4B considers the soil-root zone as the control volume, where the likelihood of reducing heavy metal concentrations with the use of plants is explored. The tool comprises three different modules that require easily quantifiable and ready available inputs (Table 1) belonging to the soil, plant, and climate compartments. The modules workflow is: (i) Spatial distribution of plant roots in the soil over the growing season; (ii) Plant-water uptake by roots; and (iii) Heavy metal release to the soil solution and subsequent uptake by roots. G4B uses the Monte Carlo method to account for environmental uncertainty, and it predicts the concentration reduction of heavy metals on a pixel-by-pixel basis. G4B is built in the statistical computing software R v. 3.2.1 (R Core Team, 2016).

To illustrate the potential of G4B, we carried out simulations on one single pixel for the hyperaccumulator fern Pteris vittata L. growing in an isotropic $1 \mathrm{~m}^{2}$ soil column containing $3000 \mathrm{ppm}$ of Arsenic (As) for a period of 9 years. The plant material was assumed to be harvested after each growing cycle. The proportion of labile As was assumed to be ca. 17 \% (Shelmerdine et al., 2009). As release was assumed to depend on the soil pH (Shelmardine et al., 2009), while soluble As was assumed to be released steadily from the soil solids to the soil solution. All the As in the soil solution was assumed to be in the form of arsenate and trasnported from the roots to the fronds. Arsenate advection and difussion was neglected. Soil mositure was assumed to be at steady-state and homogeneously distributed over the soil profile. The inputs used in the simulation are shown in Table 1. 


\section{A. Gonzalez-Ollauri, S.B. Mickovski/ Proceedings of EMCEI}

Table 1. List of input parameters/variables used to operate G4B. ${ }^{\dagger}$ mean value for the simulation period.

\begin{tabular}{|c|c|c|c|c|c|c|c|c|c|c|c|c|c|}
\hline Compartment & & & & Soil & & & & Plant & & & & Climatet & \\
\hline Input & $\begin{array}{c}\text { Sand } \\
\text { content } \\
{[\%]}\end{array}$ & $\begin{array}{c}\text { Clay } \\
\text { content } \\
{[\%]}\end{array}$ & $\begin{array}{c}\text { Organic } \\
\text { matter } \\
\text { content } \\
{[\%]}\end{array}$ & $\begin{array}{c}\text { Porosity } \\
{[\%]}\end{array}$ & $\begin{array}{c}\text { Moisture } \\
\text { content } \\
{[\%]}\end{array}$ & $\mathrm{pH}$ & $\begin{array}{c}\text { Solids- } \\
\text { solution } \\
\text { partition } \\
\text { coeff. }\end{array}$ & $\begin{array}{c}\text { Leaf area } \\
\text { index }\end{array}$ & $\begin{array}{c}\text { Max. } \\
\text { contaminant } \\
\text { uptake } \\
\text { factor }\end{array}$ & \begin{tabular}{|c} 
Mean \\
rainfall \\
intensity \\
during \\
growing \\
season \\
[mm/event]
\end{tabular} & $\begin{array}{c}\text { Mean } \\
\text { daily air } \\
\text { temp. } \\
{\left[{ }^{\circ} \mathrm{C}\right]}\end{array}$ & $\begin{array}{c}\text { Atm. } \\
\text { pressure } \\
\text { [hPa] }\end{array}$ & $\begin{array}{c}\text { Sunshine } \\
\text { duration } \\
\text { [h/day] }\end{array}$ \\
\hline Value & 74.97 & 1.6 & 5.57 & 0.68 & 0.23 & 8.5 & 0.3 & 2.5 & 0.3 & 9.14 & 8.13 & 1011.32 & 3.76 \\
\hline
\end{tabular}

\section{Results and Discussion}

The simulation outomes (Fig. 1) indicate that G4B predicted rooting depths of ca. $300 \mathrm{~mm}$ below the ground level (b.g.l.) under the considered pedoclimatic conditions (Table 1). Based on the simulation conditions and assumptions (Section 2), plants followed a cyclical pattern of activity (Fig. 1a) within the growing season (i.e. midMay - October; Fig. 1b). During the growing season, higher plant-water uptake activity during the hot days, led to higher As extractions (Fig. 1b), suggesting that phytoextraction may be more effective in warm climates.

The tested fern was able to extract, on average, $17.23 \mathrm{mg} \mathrm{L}^{-1}$ of As from the soil solution per growing cycle (Fig. 1c). Eight growing cycles would be required to reduce the concentration of As in the soil solution to safe level (DEFRA, 2002; Fig. 1c), which is in line with other published studies (Shelmerdine et al., 2009; Verma et al.,, 2006).
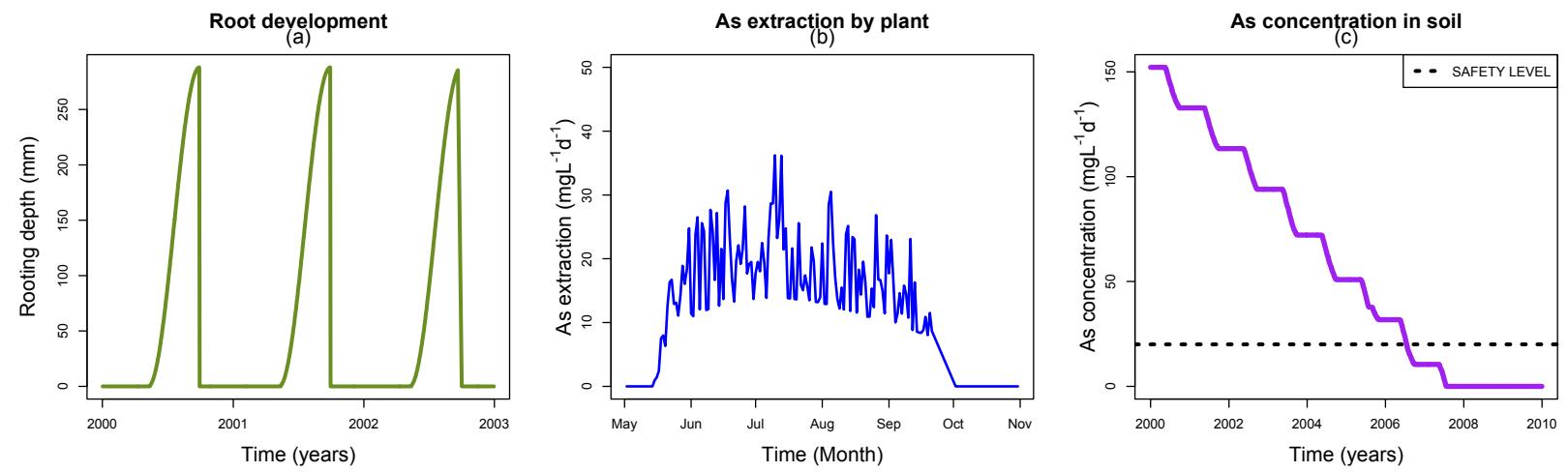

Figure 1. G4B simulation outcomes: (a) Root development in terms of rooting depth in the soil for three selected growing cycles (b) Arsenic (As) phytoextraction from the soil for a selected growing cycle (c) As concentration in the soil over time.

\section{Conclusion and Outlook}

G4B was shown to be effective and realistic for simulating phytoextraction of As from the soil. According to the simulation results, plants can be an effective measure for remediating soil polluted by heavy metals. Phytoextraction effectiveness was found to be related to the atmospheric water demand. Future work will see testing the uncertainty and sensitivity of the tool, its application on larger scales, as well as verification of the tool assumptions and behaviour through laboratory and in situ experiments.

\section{References}

[1] Glasgow and the Clyde Valley Strategic Development Planning Authority (GCVSDPA), January 2016. Clydeplan: Strategic Development Plan, Vacant and Derelict Land Monitoring Report 2014.

[2] Ansari, A A, Singh Gill, S, Gill, R, Lanza, GR, Newman, L (eds.), 2015. Phytoremediation. Management of Environmental Contaminants, Vol. 1. Springer, London, UK.

[3] Mahar, A, Wang, P, Ali, A, Awasthi, MK, Lahori, AH, Wang, Q, Li, R, Zhang, Z, 2016. Challenges and opportunities in the phytoremediation of heavy metals contaminated soils: A review. Ecotoxicology and Environmental Safety, 126, 111-121.

[4] R Core Team, 2016. R: A language and environment for statistical computing. Viena, Austria: R Foundation for statistical computing. URL: http://www.R-project.org

[5] Shelmerdine, PA, Black, CR, McGrath, SP, Young, SD, 2009. Modelling phytoremediation by the hyperaccumulating fern, Pteris vitata, of soils historically contaminated with arsenic. Environmental Pollution, 157, 1589-1596.

[6] Department of the Environment, Food and Rural Affairs (DEFRA) and the Environmental Agency, 2002. Soil Guideline Values for Arsenic Contamination. UK Environmental Agency, Bristol, UK.

[7] Verma, P, George, KV, Singh, HV, Singh, SK, Juwarkar, A, Singh, RN, 2006. Modeling rhizofiltration: heavy-metal uptake by plant roots. Environmental Modeling and Assessment, 11, 387-394. 